\title{
Intestinal absorption of food antigens in coeliac disease
}

\author{
ROBERT W PITCHER-WILMOTT, IAN BOOTH, JOHN HARRIES, AND \\ ROLAND J LEVINSKY
}

Department of Immunology and Child Health, Institute of Child Health, London

SUMMARY Serum concentrations of ovalbumin, $\beta$-lactoglobulin, and antigen-antibody complexes were measured after jejunal administration of milk and raw egg in 6 children with active coeliac disease and in 4 controls. The results did not support the hypothesis of a generalised increase in absorption of antigens from the intestinal lumen in coeliac disease.

It is well known that antigenically-intact food proteins are absorbed across the healthy gastrointestinal mucosa; ${ }^{1}$ the amounts absorbed are insignificant nutritionally but they are sufficient to immunise, and antibodies to cows' milk proteins may be found in most normal children. ${ }^{2}$ Increased absorption of food proteins has been demonstrated in infants recovering from diarrhoea ${ }^{3}$ and it has been suggested that this is owing to mucosal damage.

In coeliac disease, where profound mucosal damage occurs, it has been proposed that there may be a generalised increase in the absorption of antigens from the intestinal lumen and that an immunological response to these antigens contributes to the lesion of the small intestine. ${ }^{4}$ In common with several other gastrointestinal diseases, coeliac disease is associated with increased antibody responses to dietary proteins ${ }^{5-7}$ but there is no evidence that these antibodies are directly responsible for the intestinal disease.

To test the hypothesis that absorption of dietary antigens is increased in active coeliac disease we have measured the serum concentrations of $\beta$-lactoglobulin, ovalbumin, and antigen-antibody complexes (AAC) after administration of milk and egg to children with active coeliac disease, to children with coeliac disease in remission, and to control children.

\section{Subjects}

Ten children were studied while having a jejunal biopsy for investigation and confirmation of the diagnosis of coeliac disease. Six were having a postgluten challenge biopsy which showed severe partial villous atrophy in 5 , and subtotal villous atrophy in the sixth. Two patients were having pre-challenge biopsies while on gluten-free diets; they were free from symptoms and their biopsies were normal. Two further children in whom no organic cause was found were being investigated for suspected malabsorption and their biopsies were normal. The children therefore comprised a group of 6 patients with severe mucosal damage and 4 patients with normal mucosa.

\section{Methods}

The study was approved by the hospital's ethical committee and fully informed consent was obtained in each case. All patients were fasted overnight and, before the biopsy specimens were taken, the patients were given a mixture of milk $(10 \mathrm{ml} / \mathrm{kg}$; equivalent to $25 \mathrm{mg}$ - -lactoglobulin $/ \mathrm{kg})$ and beaten egg $(1.5$ $\mathrm{ml} / \mathrm{kg}$; equivalent to $150 \mathrm{mg}$ ovalbumin $/ \mathrm{kg}$ ) to a maximum volume of $500 \mathrm{ml}$ via a jejunal tube. Indwelling cannulae that had been inserted for drug administration during the biopsy procedure were used for blood sampling and small samples were taken just before administration of the milk/egg mixture and at 30 minutes and $1,2, \mathfrak{\prime}, 4$, and' 5 hours thereafter. Serum was separated within 2 hours, placed in aliquots, and stored at $-70^{\circ} \mathrm{C}$.

Antigen detection assays. Concentrations of ovalbumin and $\beta$-lactoglobulin were measured by a two-site solid-phase radioimmunoassay ${ }^{8}$ using polyvinyl plates. Results in $\mathrm{ng} / \mathrm{ml}$ (limits of detection about $1 \mathrm{ng} / \mathrm{ml}$ ) were read from standard curves and expressed as $\mathrm{ng} / \mathrm{ml}$ serum $/ \mathrm{g}$ antigen administered $/ \mathrm{kg}$ bodyweight. 
Antigen-antibody complexes. Circulating AAC were measured by the polyethylene glycol (PEG) precipitation method. This was performed using $12 \%$ PEG in EDTA buffer pH 7.6 diluted with sample to give a final PEG concentration of $2 \%$ and incubated overnight at $4^{\circ} \mathrm{C} .{ }^{9}$ Precipitated immunoglobulins $G, A$, and $M$ were measured by radial immunodiffusion ${ }^{10}$ and the results expressed as percentages of the total immunoglobulin concentrations of each class.

\section{Results}

Levels of ovalbumin and $\beta$-lactoglobulin were undetectable before administration of the test meal in each case. After the mixture of milk and egg had been given 4 coeliac patients showed progressive increases in serum ovalbumin concentrations (Fig. 1a) but the remaining 2 showed no evidence of absorption. Two of the 4 children with normal mucosa demonstrated absorption of ovalbumin (Fig. 1b) which was similar in degree to that seen in the 4 patients with mucosal damage.

The 2 children with normal biopsies who showed

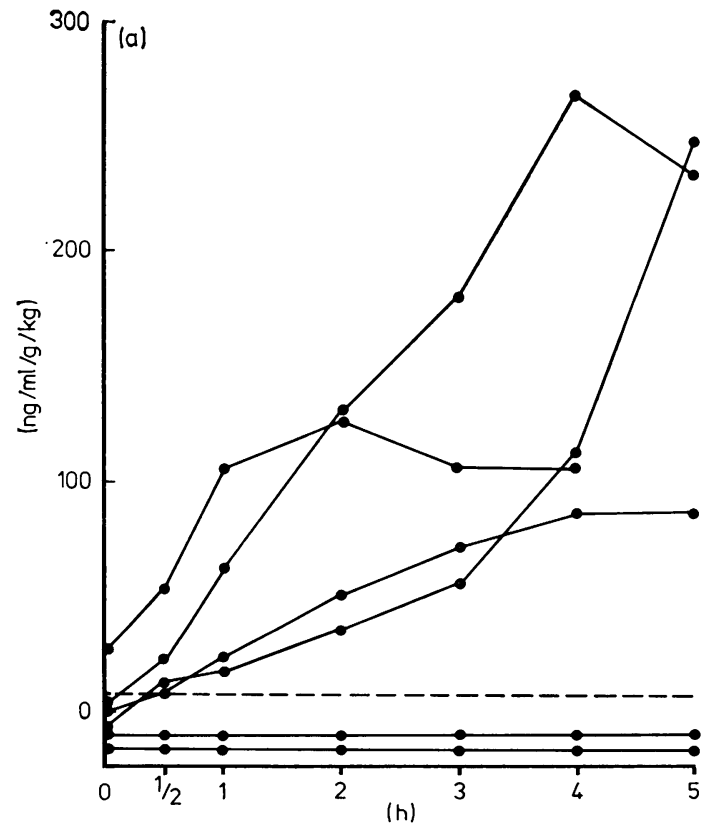

no detectable ovalbumin absorption were the coeliacs in remission. Although levels of ovalbumin did not correlate with having coeliac disease or with the degree of mucosal damage judged microscopically, the greatest degree of ovalbumin absorption occurred in a child with subtotal villous atrophy (the most severe form of mucosal damage).

There was no good evidence of $\beta$-lactoglobulin absorption in 4 of the children with active coeliac disease (Fig. 2a) although the other 2 such children had pronounced increases in $\beta$-lactoglobulin concentration after administration of the test meal. The maximum values in those 2 patients were greater than those of the 2 coeliacs in remission while the controls with normal mucosas did not develop measurable concentrations of $\beta$-lactoglobulin (Fig. $2 b)$. There was no demonstrable absorption of $\beta$-lactoglobulin in the child with subtotal villous atrophy.

None of the subjects had significant changes in IgG, IgA, or IgM complexes after antigen administration. The results for the children with normal mucosas are compared with those of the children with abnormal biopsies in the Table. One child with

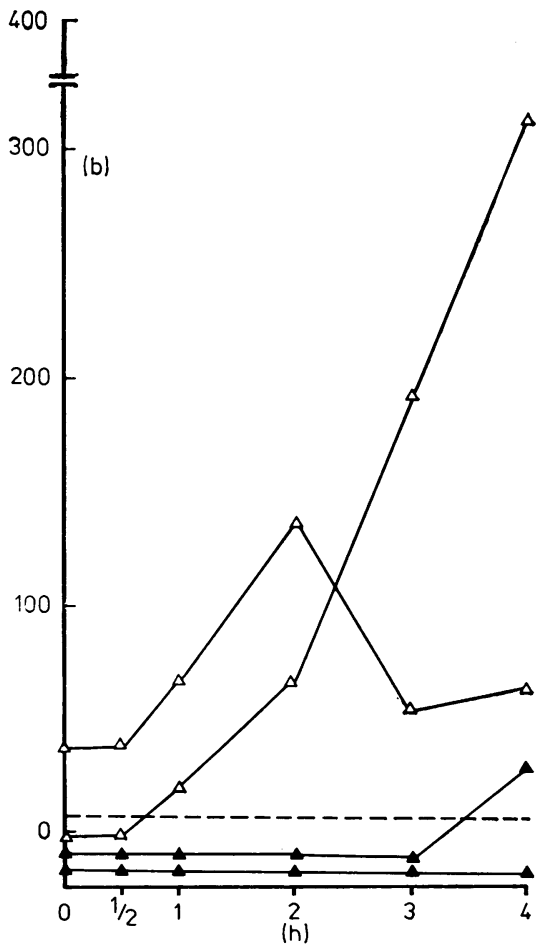

Fig. 1 Serum concentrations of ovalbumin after food provocation in (a) 6 children with active coeliac disease and (b) 4 children with normal mucosa (open triangles are the normal children and closed triangles are coeliacs in remission). The broken line indicates the limit of sensitivity for the assay. 
464 Pitcher-Wilmott, Booth, Harries, and Levinsky
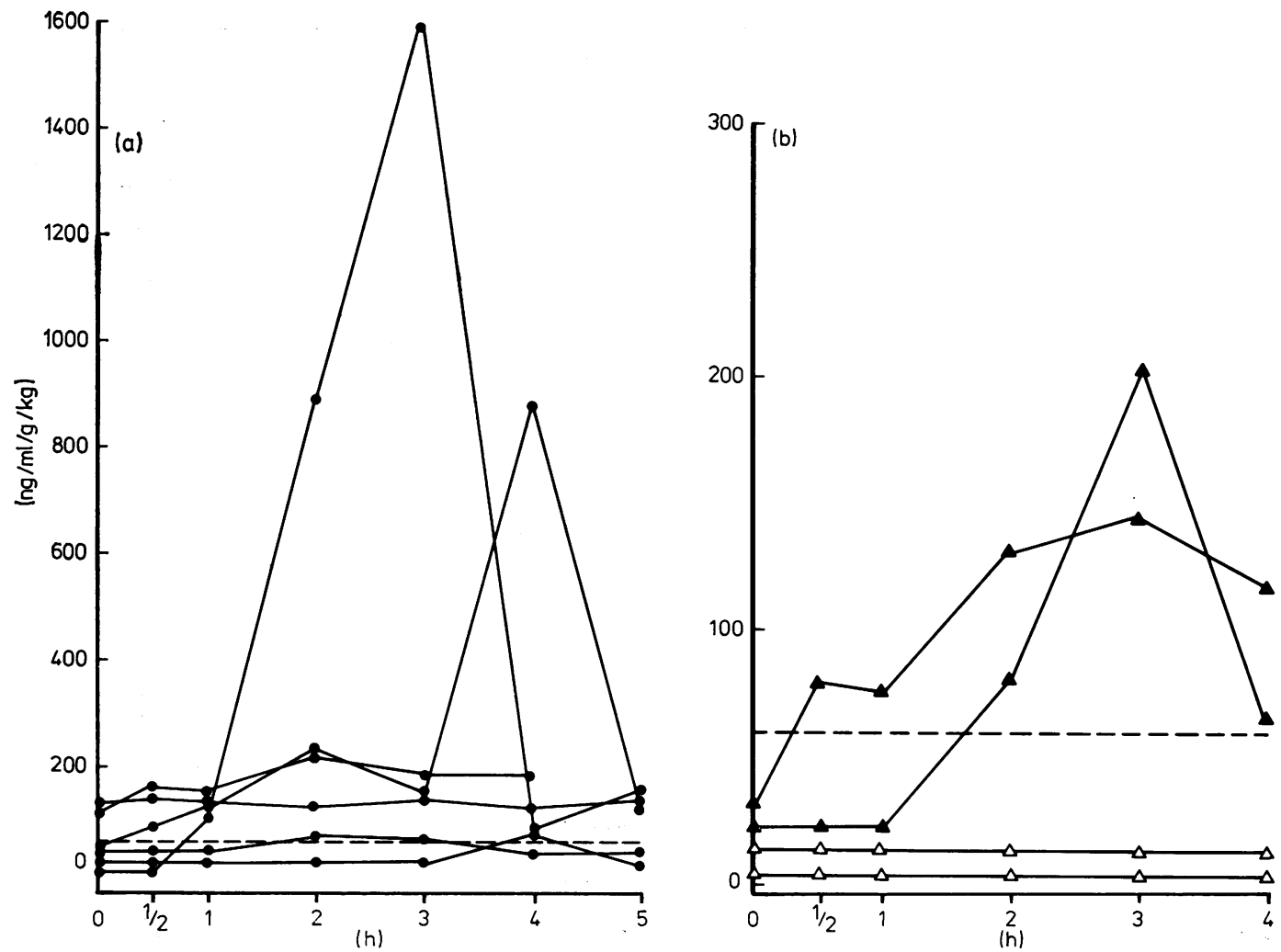

Fig. 2 Serum concentrations of $\beta$-lactoglobulin after food provocation in (a) 6 children with active coeliac disease and (b) 4 children with normal mucosa (open triangles are the normal children and closed triangles are coeliacs in remission). The broken line indicates the limit of sensitivity for the assay.

Table Antigen-antibody complex levels (mean and range) after food provocation in 6 children with active coeliac disease compared with 4 controls

\begin{tabular}{|c|c|c|c|c|c|c|c|}
\hline \multirow[t]{2}{*}{ Immunoglobulin } & \multirow[t]{2}{*}{ Before } & \multicolumn{6}{|c|}{ Time after food provocation (hours) } \\
\hline & & $30 \mathrm{~min}$ & 1 & 2 & 3 & 4 & 5 \\
\hline \multicolumn{8}{|l|}{ Patients } \\
\hline IgG & & & $1 \cdot 54$ & & 1.65 & 1.45 & \\
\hline IgA & $\begin{array}{l}1 \cdot 36-2 \cdot 44 \\
1 \cdot 01\end{array}$ & $\begin{array}{l}0.82-2 \cdot 44 \\
0.91\end{array}$ & $\begin{array}{l}0 \cdot 82-2 \cdot 49 \\
0.88\end{array}$ & $\begin{array}{l}0 \cdot 62-2 \cdot 64 \\
1 \cdot 20\end{array}$ & $\begin{array}{l}0 \cdot 93-2 \cdot 46 \\
1 \cdot 13\end{array}$ & $\begin{array}{l}0 \cdot 62-2 \cdot 63 \\
0.88\end{array}$ & $\begin{array}{l}0.94-2 \cdot 2 \\
0.78^{*}\end{array}$ \\
\hline $10 \mathrm{R}$ & $0-1.64$ & $0-1.78$ & $0-1 \cdot 60$ & $0-1.82$ & $0-1.61$ & $0-1 \cdot 30$ & $0.34-1.38$ \\
\hline IgM & 3.89 & 4.61 & $4 \cdot 26$ & $3 \cdot 71$ & 4.41 & 4.04 & $4 \cdot 21 *$ \\
\hline & $0-6.05$ & $0-9 \cdot 26$ & $0-8 \cdot 55$ & $0-6.55$ & $0-9 \cdot 26$ & $2 \cdot 08-6 \cdot 55$ & $0-6 \cdot 27$ \\
\hline \multicolumn{8}{|l|}{ Controls } \\
\hline IgG & $1 \cdot 70$ & $1 \cdot 18$ & 1.65 & 1.05 & $1 \cdot 17$ & $1 \cdot 30$ & - \\
\hline & $0.87-3.03$ & $0.65-2.03$ & $0 \cdot 70-2 \cdot 83$ & $0 \cdot 52-1 \cdot 96$ & $0 \cdot 90-1 \cdot 56$ & $0 \cdot 85-2 \cdot 28$ & - \\
\hline IgA & 1.54 & 1.33 & 1.61 & 1.01 & 1.31 & 1.06 & - \\
\hline & $0.91-2.72$ & $0.65-2.36$ & $0 \cdot 78-2 \cdot 19$ & $0.61-1.65$ & $1 \cdot 00-2 \cdot 17$ & $0 \cdot 82-1 \cdot 48$ & - \\
\hline IgM & $5 \cdot 25$ & 3.98 & $4 \cdot 08$ & $3 \cdot 85$ & $3 \cdot 74$ & 4.59 & - \\
\hline & $32 \cdot 7-7 \cdot 81$ & $2 \cdot 20-5 \cdot 19$ & $3 \cdot 13-4 \cdot 94$ & $3 \cdot 27-4 \cdot 73$ & $2 \cdot 37-5 \cdot 71$ & $3 \cdot 07-6 \cdot 29$ & - \\
\hline
\end{tabular}

* Only 5 patients as one did not complete the study.

Results are expressed as the percentage of total immunoglobulin for each class precipitated by $2 \%$ polyeth ylene glycol. 
coeliac disease was found to have IgA deficiency; this was the child who also had severe partial villous atrophy on biopsy.

\section{Discussion}

These preliminary data do not support the concept of increased permeability of gut mucosa to food antigens in active coeliac disease. The evidence in support of this theory is circumstantial and rests on the demonstration of higher levels of food protein antibodies than normal in patients with coeliac disease $^{567}$ and increased absorption of molecules such as lactulose. ${ }^{11}$ However, other studies have shown reduced absorption of small molecules-such as polyethyleneglycol 400 and urea. ${ }^{12}{ }^{13}$ The number of subjects in our study was small because of ethical constraints, but all were given equivalent amounts of antigen according to bodyweight and there were no apparent differences in absorption of $\beta$-lactoglobulin and ovalbumin between children with damaged mucosa and those with normal mucosa. The levels were similar to those seen in our earlier study of dietary antigen absorption in term infants. ${ }^{14}$ Thus we are unable to confirm the notion that a damaged mucosa is more permeable to food antigens than a normal mucosa. In addition to mucosal permeability other factors-such as gut transit time, pancreatic function, local immunity, and the extent of the damaged mucosa-could theoretically influence circulating concentrations of food antigens. However, we did not feel justified in measuring these other variables in the children. It seems likely that the serum concentrations observed were in the main a function of intestinal permeability to the antigens.

The detection of food protein antibodies in coeliac disease does not necessarily imply markedly increased absorption of food antigens because the amount of antigen required to immunise by the oral route is very small. ${ }^{15}$ Such antibodies to food proteins could indeed be associated with decreased systemic absorption of these antigens if AAC form locally and deposition occurs within the gut wall.

Further studies in animals have supported the concept that the mucosa with partial villous atrophy does not allow increased absorption of food antigens. We have studied rats infected with Nippostrongylus brasiliensis (which causes partial villous atrophy) and at the time of maximal mucosal disease there was no increase in the absorption of food proteins. ${ }^{16}$

In the earlier studies it was shown that in healthy adults and children the physiological mechanism for clearing food antigens is by the formation of small IgA complexes. ${ }^{17}$ In the present study there were no significant changes in the levels of IgG, IgA, and IgM complexes measured by polyethylene glycol precipitation, a method which detects the larger complexes which may be of more pathological significance. ${ }^{18} \mathrm{~A}$ direct assay of the antigen content of the AAC was not performed but increases seem unlikely in view of the low levels of AAC. This suggests that the AAC demonstrated in other studies of coeliac disease in remission and relapse ${ }^{19}{ }^{20}$ may have been non-specific and that they did not necessarily contain food protein antigens.

We are grateful for the advice and help given by Dr Roberto Paganelli who initially developed the food antigen assays.

\section{References}

1 Wilson S J, Walzer M. Absorption of undigested proteins in human beings. IV. Absorption of unaltered egg protein in infants and in children. Am J Dis Child 1935; 50: 49-54.

2 Peterson R D A, Good R A. Antibodies to cows' milk proteins-their presence and significance. Pediatrics 1963; 31 : 209-21.

3 Gruskay F L, Cooke R E. The gastrointestinal absorption of unaltered protein in normal infants and in infants recovering from diarrhea. Pediatrics 1955; 16: 763-9.

4 Allan Walker W. Antigen absorption from the small intestine and gastrointestinal disease. Pediatr Clin North Am 1975; 22: 731-46.

5 Taylor K B, Truelove S C, Thomson D L, Wright R. An immunological study of coeliac disease and idiopathic steatorrhoea. Serological reactions to gluten and milk proteins. Br Med J 1961; ii: 1727-31.

6 Kivel R M, Kearns D H, Liebowitz D. Significance of antibodies to dietary proteins in the serums of patients with nontropical sprue. $N$ Engl J Med 1964; 271 : 769-72.

7 Kenrick K G, Walker-Smith J A. Immunoglobulins and dietary protein antibodies in childhood coeliac disease. Gut 1970; 11: 635-40.

8 Paganelli R, Levinsky R J. Solid phase radioimmunoassay for detection of circulating food protein antigens in human serum. J Immunol Methods 1980; 37: 333-41.

- Dambuyant C, Burton-Kee J, Mowbray J F. Demonstration of two disease specific antigens in circulating immune complexes. Clin Exp Immunol 1979; 37: 424-31.

10 Mancini G, Carbonara A O, Heremans J F. Immunochemical quantitation of antigens by single radial immunodiffusion. Immunochemistry 1965; 2: 235-54.

11 Menzies I S, Pounder R, Heyer S, et al. Abnormal intestinal permeability to sugars in villous atrophy. Lancet 1979; ii: 1107-9.

12 Chadwick V S, Phillips S F, Hofmann A F. Measurements of intestinal permeability using low molecular weight polyethylene glycols (PEG 400). II. Application to normal and abnormal permeability states in man and animals. Gastroenterology 1977; 73: 247-51.

13 Fordtran J S, Rector F C, Locklear T W, Ewton M F. Water and solute movement in the small intestine of patients with sprue. J Clin Invest 1967; 46: $287-98$.

14 Roberton D M, Paganelli R, Dinwiddie R, Levinsky R J. Milk antigen absorption in the preterm and term neonate. Arch Dis Child 1982; 57: 369-72. 
15 Jarrett E E E, Haig D M, McDougall W, McNulty E. Rat IgE production. II. Primary and booster reaginic antibody responses following intradermal or oral immunization. Immunology 1976; 30: 671-7.

16 Reinhardt M C, Paganelli R, Levinsky R J, Pincott J, Harries $J$ T. Intestinal uptake of antigens in rats maintained on normal and protein deficient diets and infected with Nippostrongylus brasiliensis (abstract). Immunobiology 1981; 160: 92 .

17 Brostoff J, Carini C, Wraith D G, Paganelli R, Levinsky R J. Immune complexes in atopy. In: Pepys J, Edwards A M, eds. The mast cell. London: Pitman, 1979: 380-93.

18 World Health Organisation Scientific Group. The role of immune complexes in disease. Technical Report Series No 606. Geneva: WHO, 1977: 5-58.
19 Mohammed I, Holborow E J, Fry L, Thompson B R, Hoff brand A V, Stewart J S. Multiple immune complexes and hypocomplementaemia in dermatitis herpetiformis and coeliac disease. Lancet 1976; ii: 487-90.

20 Doe W F, Booth C C, Brown D L. Evidence for complement-binding immune complexes in adult coeliac disease, Crohn's disease, and ulcerative colitis. Lancet 1973; i: 402-3.

Correspondence to Dr R J Levinsky, Institute of Child Health, 30 Guilford Street, London WC1N 1 EH.

Received 8 December 1981

\section{British Paediatric Association}

$\begin{array}{ccc}\text { Annual meetings } & \\ 1983 & 12-16 \text { April } & \text { York University } \\ 1984 & 10-14 \text { April } & \text { York University } \\ 1985 & 16-20 \text { April } & \text { York University } \\ 1986 & 15-19 \text { April } & \text { York University }\end{array}$

